\title{
ANALISIS GENDER DALAM CERITA RAKYAT (KAJIAN SEMIOTIKA ROLAND BARTHES) GENDER ANALYSIS IN FOLKLORE (THE SEMIOTIC STUDY OF ROLAND BARTHES)
}

Naskah masuk: 17 Januari 2021, direview: 21 April 2021, disetujui: 25 April 2021

\author{
Siti Hardiyanti Amri \\ STKIP Muhammadiyah Barru \\ Pos-el: siti.hardiyanti.a@mail.ugm.ac.id \\ Ponsel: 082394590900
}

\begin{abstract}
ABSTRAK
Tulisan ini membahas tentang relasi gender dalam dua cerita rakyat berjudul Tempiq Empiq dari Nusa Tenggara Barat dan Mencari Ilmu Berumahtangga dari Kalimantan Selatan. Hubungan hierarki dianalisis dengan perspektif semiologis Roland Barthes. Metode penelitian terdiri dari pengumpulan data dan analisis data. Data primer dalam penelitian ini adalah cerita rakyat. Sedangkan data sekunder berupa sumber tertulis dan elektronik terkait dengan kondisi sosial budaya dan sejarah Nusa Tenggara Barat dan Kalimantan Selatan. Analisis data dilakukan dengan teori dan konsep Barthes sebagai pendekatan untuk mengetahui sistem semiotik orde satu dan dua yang mengungkap mitos-mitos terkait isu gender dalam teks. Setelah itu, mitos-mitos yang terkandung dalam teks tersebut dihubungkan dengan niat, motivasi, atau ideologi tertentu yang diyakini pada budaya atau masyarakat tertentu sebagai latar belakang cerita rakyat tersebut. Hasil penelitian menemukan bahwa analisis sistem kebahasaan teks mengungkapkan dikotomi peran dan fungsi antara laki-laki dan perempuan. Analisis makna konotatif menemukan mitos-mitos seksualitas dan maskulinitas yang mengacu pada ideologi patriarki.
\end{abstract}

Kata kunci: Cerita Rakyat, Semiologi, Barthes, Mitos

\begin{abstract}
This paper studied about gender relation in two folklores entitled Tempiq Empiq from Nusa Tenggara Barat and Mencari Ilmu Berumabtangga from Kalimantan Selatan. The hierarchical relationship was analyzed by the semiological perspective of Roland Barthes. The research method consisted of data collection and data analysis. The primary data in this research was the folklores. Meanwbile, the secondary data was the written and electronic sources related to the socio-cultural and historical condition of Nusa Tenggara Barat and Kalimantan Selatan. The data was analyzed by the the theory and concepts of Barthes as the approach to find out the first and second order semiotic system revealing the myths related to the gender issues in the text. Afterwards, the myths contained in the text were connected to the specific intention, motivation, or ideology believed in particular culture or society as the background of the folklores. The research found that the analysis of linguistic system of the text revealed the dichotomy of roles and function between men and women. The analysis of connotative meaning found the myths of sexuality and masculinity which referred to patriarchal ideology.
\end{abstract}

Keywords: Folklores, Semiology, Barthes, Myths 


\section{PENDAHULUAN}

\subsection{Latar Belakang}

Karya sastra sebagai culture regime memiliki daya pikat yang kuat terhadap persoalan gender. Pandangan tentang karakteristik perempuan sebagai makhluk yang lemah lembut atau halus budi pekertinya, dan sebaliknya laki-laki sebagai sosok yang kuat, cerdas, dan aktif senantiasa mewarnai sastra nusantara. Citra mengenai perbedaan peran perempuan dan laki-laki seolah telah tertanam dan mengakar dalam diri masyarakat. Sebagian besar karya satra selalu menunjukkan hegemoni dan dominasi laki -laki terhadap perempuan. Laki-laki dideskripsikan sebagai pemegang tampuk kekuasan atau the authority, sedangkan perempuan sebagai makhluk kelas dua atau the second sex yang berada dalam posisi subordinat atau marginal (Endraswara, 2011:143). Dualisme peran laki-laki dan perempuan dalam aspek-aspek kehidupan sebagai bagian dari suatu kebudayaan menjadi tema sentral yang diangkat dalam sastra tulis maupun lisan.

Salah satu genre sastra lisan adalah cerita rakyat. Cerita rakyat merupakan tradisi dan bagian dari suatu kebudayaan tertentu yang dituturkan dari satu generasi ke generasi selanjutnya. Selain sebagai sarana hiburan, cerita rakyat memiliki peranan yang penting sebagai media pendidikan karakter, etika, dan penanaman nilai-nilai moral. Cerita rakyat tersebar dan berkembang di tengah-tengah masyarakat, tentu merepresentasikan pandangan dan prinsip kehidupan masyarakat yang melatarbelakangi terciptanya cerita tersebut. Mayoritas cerita rakyat mengemukakan bias gender dan menekankan dikotomi atau perbedaan peran dan fungsi perempuan dan laki-laki dalam ranah domestik dan publik. Kehadiran cerita rakyat yang mendeskripsikan pembagian aktivitas antara laki-laki dan perempuan justru semakin melanggengkan dan melestarikan perspektif masyarakat terkait sikap atau perilaku perempuan dan laki-laki dalam kehidupan sehari-hari. Perbedaan yang terbentuk dari sistem kebudayaan akan mengarah kepada sebuah struktur hierarki, yakni dominasi dan superioritas yang tumbuh dalam diri seorang laki-laki dan posisi subordinat dan inferior yang tertanam dalam jiwa perempuan. Hal ini pada akhirnya mengarah kepada sebuah tindakan diskriminatif atau perlakuan yang berbeda terhadap keduanya. Seperti yang dikemukakan oleh Banton (1994: 1) "Discrimination on ground of sex (or gender) occurs when someone supposed to be female is treated differently from someone supposed to be male (or vice versa)." Diskriminasi dalam ranah gender terjadi jika seorang perempuan diperlakukan dengan cara yang berbeda dari seorang laki-laki begitupun sebaliknya.

Fakih (1997:8-10) mengemukakan lebih lanjut bahwa gender merupakan sebuah konsep yang melekat pada kaum laki-laki maupun perempuan. Misalnya, perempuan adalah sosok yang lemah, cantik, emosional serta keibuan. Sementara lakilaki dianggap kuat, rasional, jantan, dan perkasa. Jika melihat sejarah, konsep gender sendiri telah berlangsung sangat lama dan dibentuk, disosialisasikan, diperkuat, bahkan dikonstruksi secara sosial dan kultural. Melalui proses yang panjang, sosialisasi mengenai pengertian dan konsep gender akhirnya dipandang sebagai ketentuan Tuhan berakar dari ciri biologis yang tidak dapat diubah lagi sehingga perbedaan gender yang terbentuk dipahami sebagai kodrat perempuan dan laki-laki. Karena konstruksi sosial gender yakni kaum laki-laki harus bersifat kuat dan agresif, maka kaum laki-laki akhirnya terlatih dan tersosialisasi serta termotivasi untuk menjadi atau menuju ke sifat gender yang ditentukan oleh masyarakat, begitupula yang terjadi pada perempuan yang diperkenalkan dengan sejumlah sifat dan karakter perempuan yang lemah lembut sehingga mempengaruhi emosi dan ideologi perempuan. Hal ini sejalan dengan persoalan tema bias gender yang seringkali diangkat dalam cerita rakyat. Cerita rakyat sebagai sarana pendidikan tehadap anak justru menyosialisasikan dan menanamkan 
ideologi dualisme posisi, karakteristik, peran serta, dan fungsi perempuan dan laki-laki dalam kehidupan.

Oleh karena itu, analisis relasi gender dalam dua cerita rakyat yang berjudul Tempiq Empiq (Nusa Tenggara Barat) dan Mencari Ilmu Berumah Tangga (Kalimantan Selatan) dilakukan dalam kerangka teori dan konsep-konsep pakar semiotika Roland Barthes. Analisis sistem semiologi dalam kedua cerita rakyat tersebut bertujuan untuk menyingkap relasi hirarki gender yang dapat ditelusuri melalui simbol-simbol atau tanda yang terdapat pada teks. Analisis sistem semiologi tingkat pertama dan kedua pada akhirnya mengungkapkan mitos dan ideologi yang terkandung dalam kedua cerita tersebut.

\subsection{Masalah}

Untuk mengidentifikasi isu gender yang terkandung dalam cerita rakyat, maka permasalahan yang akan diungkapkan dalam tulisan ini adalah sistem linguistik, sistem mitos, dan ideologi yang terkandung dalam cerita rakyat Tempiq Empiq dan Mencari Ilmu Berumah Tangga.

\subsection{Tujuan Penelitian}

Penelitian ini bertujuan untuk mengemukakan sistem linguistik, sistem mistis, dan ideologi yang terkandung dalam cerita rakyat Tempiq Empiq dan Mencari Ilmu Berumah Tangga berdasarkan perspektif semiotika Roland Barthes.

\subsection{Kajian Pustaka}

Berdasarkan penelusuran beberapa sumber pustaka, ditemukan beberapa penelitian terhadap cerita rakyat dengan menggunakan berbagai pendekatan. Noy, dkk. (2016) menganalisis cerita rakyat Daya Buak yang berasal dari suku Dayak Mualang, Kalimantan Barat. Ada dua aspek yang menjadi fokus peneliti, yaitu unsur instrinsik dan unsur ekstrinsik atau peneliti menyebutnya dengan nilai-nilai yang membangun cerita tersebut. Teori dalam penelitian ini tidak dipaparkan secara eksplisit, peneliti hanya menjabarkan bahwa peneltian yang dilakukannya merupakan penelitian deskriptif kualitatif tanpa mengemukakan prosedur yang ditempuh untuk mengidentifikasi unsur-unsur intrinsik dan ekstrinsik dari karya yang diteliti. Keilmiahan dan keobjektifan analisis semakin dipertanyakan Ketika peneliti hanya menyebutkan bahwa teknik analisis data nya adalah teknik analisis data kualitatif. Hasil penelitian mengemukakan unsur-unsur intrinsik seperti tema kesabaran, alur maju, sejumlah latar, lima tokoh utama, lima poin amanat yang tidak disebutkan secara jelas, serta nilai-nilai agama, moral, sosial dan budaya tanpa adanya pemaparan data-data temuan yang mendukung sejumlah aspek yang diteliti tersebut.

Junaini, dkk. (2017) mengkaji nilai-nilai pendidikan karakter yang terkandung dalam cerita rakyat yang berasal dari daerah Seluma, Provinsi Bengkulu. Untuk mengidentifikasi nilai-nilai tersebut, peneliti menggunakan teori Thomas Lickona yang membagi pendidikan karakter ke dalam tiga poin utama, yaitu knowing the good yang artinya mengetahui atau memahami kebaikan, desiring the good atau mendambakan dan senang terhadap kebaikan itu sendiri, dan terakhir doing the good yang bermakna melakukan kebaikan. Ketiga indikator inilah yang kemudian dijadikan tolak ukur peneliti dalam mengidentifikasi nilai-nilai pendidikan karakter yang terdapat dalam cerita. Peneliti mengemukakan bahwa pendekatan struktural digunakan untuk menganalisis struktur teks, akan tetapi tidak dikemukakan secara jelas prosedur ilmiah untuk menganalisis struktur cerita yang disadur dari bentuk lisan ke tulisan tersebut. Peneliti hanya mengidentifikasi struktur instrinsik teks. Hal ini semakin jelas terlihat di bagian metode. Cara kerja yang ditempuh adalah deskriptif kualitatif untuk menganalisis kandungan dari cerita. Peneliti hanya menyebutkan jenis metode tanpa 
menjelaskan bagaimana cara untuk menganalisis isi atau yang dikatakan peneliti sebagai analisis konten. Hasil penelitian terhadap sebelas judul cerita rakyat dari dua kecamatan yang berbeda di Seluma menunjukkan bahwa terkandung sejumlah nilai pendidikan karakter dalam cerita tersebut, antara lain nilai keberanian, kejujuran, kedisiplinan, rasa hormat, tanggung jawab, dan kepedulian terhadap sesama.

Peneliti lain yang juga turut menganalisis cerita rakyat adalah Nasiru (2017) dalam penelitiannya yang berjudul "Transformasi dari "Liyan" ke Diri dalam Tiga Cerita Rakyat Kulisusu: Analisis Wacana Feminisme. Peneliti dalam hal ini mengkaji tokoh-tokoh perempuan yang beralih posisi yang semula the other, Liyan, atau yang Lain menjadi diri/selfhood dalam tiga cerita rakyat Kulisusu, Sulawesi Tenggara. Peneliti menggunakan teori feminisme Simone de Bouvoir untuk menemukan kategori-kategori perempuan sebagai Liyan dan upaya-upaya eksistensi perempuan dalam teks. Penelitian ini menemukan bentuk-bentuk domestifikasi, objektifikasi, dehumanisasi atas tubuh dan identitas perempuan. Selain itu, penelitian ini melihat adanya pergerakan yang dilakukan perempuan untuk melepaskan diri dari ikatan norma sosial, budaya, agama menuju identitas yang bebas

Selain beberapa penelitian terdahulu yang telah dipaparkan sebelumnya, terdapat penelitian terhadap cerita rakyat dengan pendekatan semiotika. Safiuddin (2019) melakukan studi terhadap cerita rakyat Wandiu-Ndiu yang berasal dari Buton, Sulawesi Tenggara. Peneliti memfokuskan analisisnya terhadap aspek-aspek semiotika seperti kode-kode tersembunyi, amanat, dan fungsi sosial yang ditemukan dalam teks. Konsep-konsep semiotika Roland Barthes digunakan untuk mengidentifikasi mitos atau tataran signifikasi tingkat dua. Hasil penelitian menunjukkan sejumlah kode, antara lain kode hermeneutik, kode proairetik/aksi, kode semik/konotatif, kode simbol, dan kode budaya. Selain itu, peneliti juga mengidentifikasi amanat atau pesan persaudaraan dan kepatuhan terhadap orang tua. Adapun fungsi sosial yang ditemukan, yaitu fungsi kebudayaan, pendidikan, dan kemasyarakatan. Peneliti dalam melakukan analisisnya, tidak fokus membahas terkait mitos atau tataran makna dilapis kedua, melainkan menyajikan sejumlah konsep-konsep semiotika secara umum tidak dikhususkan pada konsep Barthes.

Berdasarkan pemaparan beberapa penelitian di atas, studi cerita rakyat dari berbagai wilayah di Indonesia telah banyak dilakukan. Akan tetapi, penelitian cerita rakyat yang berasal dari Nusa Tenggara Barat dan Kalimantan Selatan belum pernah dilakukan sebelumnya. Selain itu, penelitian ini akan fokus mengidentifikasi mitos yang terdapat pada teks berdasarkan konsep-konsep semiotika yang dikemukakan oleh Roland Barthes untuk mengetahui tataran makna lapis kedua dari teks yang menjadi objek penelitian.

\subsection{Landasan Teori}

Analisis persoalan gender dalam cerita rakyat dilakukan dengan menggunakan teori semiotika yang merupakan ilmu tentang sistem tanda. Cerita rakyat yang merupakan salah satu jenis sastra merupakan struktur dan sistem tanda-tanda yang bermakna yang menggunakan bahasa sebagai mediumnya. Tanpa memperhatikan sistem dan konvensi tanda dan maknanya maka makna yang optimal tidak dapat dicapai. Semiotika memandang bahwa fenomena sosial/masyarakat dan kebudayaan merupakan tanda-tanda (Pradopo, 2013: 118-121). Sejalan dengan pengertian ini, Sugihastuti (2011: 117-121) mengemukakan bahwa menganalisis sastra dengan pendekatan semiotik berarti melihatnya sebagai sebuah unit budaya, suatu entitas. Unit tersebut bisa berupa benda, peristiwa, perasaan, firasat, harapan, atau ide. Memahami persoalan gender dalam karya sastra berarti melihatnya sebagai sebuah unit budaya 
yang dapat ditentukan secara semiotik sebagai suatu unit semantik yang merupakan sebuah sistem. Jadi, untuk mengetahui wacana bias gender dalam sastra, maka harus dipandang secara semiotik yakni peneliti memiliki kesadaran, perasaan, gambaran, konsepsi, dan representasi yang berfungsi sebagai tanda. Dalam proses analisis, peneliti menghubungkan jalinan tanda secara bersama. Tanda itulah yang disebut ideologi. Dalam ideologi, objeknya ialah suatu pandangan dunia yang diorganisasikan pada analisis semiotik. Dengan kata lain, isu bias gender dalam sastra khususnya dalam cerita rakyat dapat diidentifikasi dengan melihatnya sebagai objek semiotik yang membutuhkan penggalian makna di tataran konotasi.

Terkait dengan makna dalam tataran konotasi, seorang tokoh semiotika terkemuka, Roland Barthes (1981:89) mengemukakan bahwa sastra merupakan wacana, sebuah sistem signifikasi sarat pesan yang terdiri dari lapisan ekspresi dan lapisan konten/makna. Ada dua sistem signifikasi yakni sistem pertama yang merupakan tataran makna denotasi dan sistem kedua yang merupakan lapisan konotasi. Sistem kedua ini merupakan perluasan dari sistem yang pertama. Hal ini lebih lanjut dijelaskan oleh Faruk (2015:82) bahwa karya sastra merupakan second order semiotic system yang disertakan pada primary semiotic system yang berupa bahasa. Satuan tanda dan makna dalam sistem semiotik tingkat pertama menjadi tanda dalam semiotik tingkat kedua. Jadi, bahasa sebagai medium sastra atau cerita rakyat merupakan sistem semiotik tingkat pertama yang berada pada lapisan makna denotatif atau literal sedangkan sastra itu sendiri berada pada sistem semiotik tingkat dua yang berada pada lapis makna konotatif.

Barthes (1957: 107) dalam bukunya yang berjudul Mythologies mengemukakan bahwa mitos adalah sebuah tipe atau jenis tuturan, suatu sistem komunikasi yakni sebuah pesan. Mitos adalah signifikasi. Segala sesuatu bisa menjadi mitos sepanjang disampaikan melalui wacana. Barthes (1957: 113-114) memperkenalkan istilah tridimensional pattern dalam mitos yang terdiri dari signifier, signified, dan sign. Mitos terbentuk dari rantai semiologi yang ada sebelumnya yakni yang disebut a second order semiological system atau sistem semiologi tingkat dua. Dengan kata lain, tanda yang terdapat pada tingkat atau lapis pertama menjadi penanda pada tingkat dua. Oleh karena itu, mitos disebut metabahasa karena merupakan kalimat kedua yang berbicara mengenai kalimat pada level atau tataran yang pertama. Barthes (1981: 89) menjelaskan lebih lanjut bahwa sistem signifikasi terdiri atas tingkatan ekspresi yang dikenal dengan simbol (E) expression dan tingkatan arti/makna (C) content yang saling berelasi (R) relation. Simbol-simbol ini kemudian dirumuskan menjadi ERC. Jadi, pandangan Hjelmslev yang diadopsi oleh Barthes memaparkan bahwa sistem pertama (ERC) menjadi tingkatan ekspresi atau penanda bagi sistem kedua. Dipertegas lagi oleh Hjelmslev (Barthes, 1974: 7) connotation is a secondary meaning, whose signifier is itself constituted by a sign or system of primary signification, which is denotation. Sistem pertama merupakan lapisan denotatif sedangkan sistem kedua adalah lapisan konotatif yang merupakan perluasan dari sistem pertama.

Melalui pendekatan semiotika Roland Barthes, maka mitos dalam cerita rakyat Tempiq Empiq dan Mencari Ilmu Berumah Tangga dianalisis dan diidentifikasi melalui bahasa yang terdiri dari sistem tanda, melalui unsur-unsur internal atau informasi yang tersedia dalam teks, lalu mengaitkannya dengan ideologi suatu masyarakat dalam budaya tertentu.

\subsection{METODE PENELITIAN}

\subsection{Metode Pengumpulan Data}


Pengumpulan data penelitian dilakukan melalui studi Pustaka. Data primer dalam penelitian ini adalah cerita rakyat Tempiq Empiq yang berasal dari Nusa Tenggara Barat dan Mencari Ilmu Berumah Tangga yang berasal dari Kalimantan Selatan. Adapun data pendukung berupa sumber-sumber tertulis seperti buku dan jurnal dan sumber elektronik yang berkenaan dengan kondisi sosio-kultural dan historis Nusa Tenggara Barat dan Kalimantan Selatan.

\subsection{Metode Analisis Data}

Berdasarkan kerangka pemikiran semiotika Roland Barthes, berikut tahapan analisis data dalam penelitian ini;

a. Melakukan pembacaan terhadap data primer

b. Mengidentifikasi sistem linguistik atau lapisan makna tingkat pertama (pemaknaan denotatif teks)

c. Menemukan sistem mitis (mitos) atau lapisan pemaknaan di tataran kedua secara konotatif.

Menemukan ideologi, intensi, atau kepentingan yang terdapat dalam kedua cerita rakyat tersebut. Tulisan-tulisan terkait Nusa Tenggara Barat dan Kalimantan Selatan

mendukung pengungkapan historisitas atau konteks kelahiran mitos dalam cerita.

\section{PEMBAHASAN}

\subsection{Sistem Linguistik Cerita Rakyat}

\section{Tempiq Empiq}

Analisis terhadap cerita rakyat Tempiq Empiq dimulai dengan identifikasi sistem linguistik atau yang disebut oleh Barthes sebagai bentuk. Bentuk dalam hal ini adalah bagian cerita rakyat tersebut atau unsur-unsur pembangun cerita yang meliputi tokohtokoh, peristiwa, ruang dan waktu. Tempiq Empiq merupakan cerita rakyat yang berasal dari daerah Nusa Tenggara Barat (NTB) yang diterjemahkan dari bahasa sasak. Adapun tokoh-tokoh yang terdapat dalam cerita, antara lain sang ayah yang bernama Amaq Tempiq-Empiq, Inaq Tempiq Empiq sebagai ibu dan anak pertamanya bernama Tempiq-Empiq yang menjadi judul cerita. Kata tempiq empiq berasal dari kata empiq yang berarti kerak nasi. Karena memiliki kebiasaan memakan kerak nasi, anak ini dijuluki Tempiq Empiq. Latar ruang dalam cerita adalah rumah yang berlokasi di sebuah dusun di Kecamatan Pujut. Selain rumah, latar lain dalam cerita adalah hutan karena mata pencaharian utama kepala keluarga adalah mencari kayu api di hutan sehingga sebagian besar aktivitas berlangsung di rumah dan hutan.

Cerita berjalan dengan pembagian tugas yang sangat jelas antara ayah dan ibu. Amaq bekerja setiap hari mengumpulkan kayu di hutan, sementara Inaq bertugas dalam wilayah domestik dalam hal memasak dan mengurus kedua anaknya. Amaq digambarkan sebagai sosok yang temperamental, tidak segan-segan melakukan kekerasan verbal dan fisik kepada anggota keluarganya. Peristiwa yang terjadi dalam cerita ditandai dengan kepergian sang ibu dari rumah melakukan perjalanan menuju pantai dan tinggal di sebuah gua yang bentuknya menyerupai hunian seperti rumah. Gua dalam cerita menunjukkan ruang lain yang dihuni oleh tokoh. Inaq sang ibu kemudian menjadi sosok mistis yang memiliki kemampuan mengeluarkan suara dibalik gua sebagai pertanda akan datangnya musim hujan yang bisa membawa kemakmuran atau musibah berupa wabah penyakit. Selain itu, sang ibu menitipkan sebuah telur kepada anak-anaknya yang pada akhirnya menetas menjadi seekor anak ayam yang kemudian dirampas oleh sang ayah yang menggunakannya untuk adu ayam. Ayam itu selalu membawa keberuntungan dan kemenangan baginya. Waktunya tergerus mengadu ayam, anak-anaknya menjadi terlantar dan memilih bermain di pohon ara. 
Pohon juga menjadi latar dalam cerita. Suatu saat anak-anak ini berubah menjadi burung yang bersayap. Perubahan dari manusia menjadi binatang dan perubahan karakter sang suami menjadi sosok yang peduli terhadap makhluk mistis penghuni gua yang tak lain adalah isterinya menandai akhir cerita. Jadi, pembacaan terhadap tokohtokoh, peristiwa, ruang atau latar dapat diringkas sebagai berikut:

Tokoh-tokoh : manusia (ayah, ibu, Tempiq Empiq sebagai anak) bukan manusia (makhluk mistis gua, burung bersayap)

Ruang/Latar : rumah, hutan, gua, pohon ara

Peristiwa : perjalanan, perubahan wujud

\section{Mencari Ilmu Berumah Tangga}

Cerita rakyat Mencari Ilmu Berumah Tangga merupakan cerita yang berasal dari daerah Kalimantan Selatan. Adapun tokoh-tokoh dalam cerita ini, yaitu seorang putri saudagar yang hendak dipinang oleh anak Raja. Perempuan ini kemudian ditugaskan untuk mencari seorang guru yang dapat mengajarinya ilmu berumah tangga. Guru diperankan oleh seorang nenek yang menguasai pengetahuan seputar rumah tangga dan bersedia memberikannya pelajaran. Tokoh nenek dalam hal ini memiliki pengaruh yang signifikan terhadap sikap dan perilaku perempuan tersebut melalui serangkaian petuah dan wejangan. Wejangannya berupa keharusan perempuan untuk melayani suami di segala aspek kehidupan berumah tangga, sikap pasif sebagai hal yang mulia dan bernilai ibadah bahkan jika terjadi penyelewengan atau perselingkuhan, kekerasan dalam keluarga adalah hal yang lazim menurut sang nenek. Selain itu, nenek itu berpesan bahwa hal terpenting yang seorang perempuan harus jaga adalah penyerahan diri sepenuhnya kepada suami, kepatuhan dan rasa hormat, serta ibadah kepada Tuhan. Perempuan ini terdoktrinasi dan memegang teguh nilai-nilai yang harus dijunjung seorang isteri sesuai dengan petunjuk yang disampaikan oleh nenek tersebut. Nenek dalam cerita ini memegang peranan yang cukup penting karena pada akhirnya mempengaruhi tokoh perempuan tersebut untuk menerima lamaran anak Raja.

Tokoh utama lain dalam cerita adalah anak raja yang ternyata memiliki tabiat yang buruk. Dikisahkan ia gemar berselingkuh dan tidak menjalankan peran dan tanggung jawab sebagai suami. Sang raja murka lalu memerintahkan anaknya untuk berlayar dan berniaga. Peristiwa dalam cerita berupa perpisahan dan perjalanan yang dilakukan oleh baik si perempuan dalam mencari ilmu berumah tangga dan juga si lakilaki dalam bekerja. Lelaki tersebut dalam perjalanan pun bertemu dengan tokoh lainnya. Seorang kakek yang memintanya untuk menguji istri dan perempuan lainnya. Ternyata di antara para perempuan yang menginginkan materi atau barang berharga darinya, istrinya hanya memintanya untuk mendapatkan dan membeli akal dan pikiran, sesuatu yang akhirnya membuatnya merenungi kesalahan-kesalahannya di masa lalu dan memberikan pencerahan padanya mengenai kesetiaan dan ketulusan istrinya.

Tokoh-tokoh : perempuan (tanpa nama), nenek, anak Raja, sang Raja, kakek

Ruang/latar : rumah, lautan

Peristiwa : perjalanan

\subsection{Sistem Mitis dalam Cerita Rakyat}

\section{Relasi Gender dan Mitos Seksualitas}

a. Tempiq Empiq

Analisis pada lapis makna denotatif telah diungkapkan pada bagian sebelumnya. Pembacaan dan pengkajian pada makna di lapisan pertama atau disebut Barthes sebagai semiotika tingkat pertama menjadi landasan untuk melakukan analisis secara komprehensif makna pada lapisan kedua. Pada tataran literal, cerita rakyat Tempiq Empiq merupakan cerita sederhana terkait problematika kehidupan keluarga yang 
dibumbuhi dengan makhluk fantasi, hal ini ditandai dengan perubahan wujud tokoh di dalamnya. Pemilihan kata tempiq empiq sebagai judul dan nama keluarga dalam cerita terbilang janggal dan menimbulkan tanda tanya. Meskipun kata tempiq empiq berasal dari kata empiq/mpiq yang berarti kerak nasi dalam bahasa masyarakat Lombok, jika ditelisik lebih lanjut, kata tempiq ini memiliki kemiripan dengan kata tempik yang bermakna organ intim wanita yang tergolong kasar dalam bahasa Jawa. Selain itu, kata empik menurut KBBI berarti sangat menginginkan atau berhasrat terhadap sesuatu. Kemiripan kedua kata tersebut tidak mustahil mengingat bahasa Sasak berada dalam rumpun bahasa Austronesia. Penggabungan kedua kata menjadi sebuah frasa vulgar yang bermuatan negatif. Ini mengindikasikan bahwa kehadiran perempuan sangat esensial dalam keluarga. Perempuan sebagai ibu, tempat bergantung yang mengurus dan merawat anak -anak. Di sisi lain, ibu hanya menjadi objek seksual bagi ayah.

Relasi gender mewarnai cerita rakyat ini. Relasi gender merupakan relasi hierarki antara perempuan dan laki-laki yang ditentukan oleh sosial budaya dan dianggap alamiah yang cenderung merugikan perempuan. Perempuan dianggap berperan dalam urusan domestik yang kemudian membatasi ruang lingkup perempuan di ranah publik sedangkan laki-laki bertugas mencari nafkah dan beraktivitas di luar rumah untuk menghidupi keluarganya. Pembagian peran antara perempuan dan lakilaki ini kemudian mengarah kepada relasi hierarki sehingga laki-laki merasa memiliki kontrol dan kekuasaan penuh terhadap isteri. Sugihastuti dan Saptiawan (2007: 54) mengemukakan bahwa pembagian peran dan aktivitas berdasarkan gender menghasilkan status diferensial. Pekerjaan laki-laki atau arena laki-laki memiliki kekuatan kemasyarakatan yang lebih besar. Laki-laki pada sebagian besar budaya, memiliki akses pada posisi publik sehingga dipandang lebih berpengaruh dan kuat dibanding perempuan. Di sisi lain, ruang gerak perempuan dibatasi pada wilayah domestik, privat, atau nonpublik. Dengan kata lain, sebagian besar kebudayaan memiliki perspektif dan pandangan hidup mengenai perbedaan fungsi perempuan dan laki-laki. Laki-laki dipandang memiliki kewajiban dan tugas untuk mengayomi dan menafkahi keluarga dengan bekerja di sektor publik, sedangkan perempuan bertugas mengurus segala keperluan rumah tangga serta merawat dan membesarkan anakanaknya.

Cerita Rakyat Tempiq Empiq melukiskan dikotomi peran antara istri dan suami. Mata pencaharian utama keluarga adalah mencari kayu api di hutan dan hal ini merupakan peran dan beban kerja yang dimiliki suami yang bertugas menafkahi istri dan kedua anaknya. Istri dipandang memiliki kewajiban untuk memenuhi dan melayani segala kebutuhan suami juga merawat dan mengasuh anak-anak. Pembagian kerja ini mengarah kepada kekuasaan yang dimiliki suami dan cenderung memojokkan posisi istri dalam keluarga. Pembagian peran dapat dilihat melalui kutipan berikut.

Mata pencaharian keluarga ini hanya dengan mencari kayu api di hutan yang letaknya tidak jaub dari pondok mereka. Setiap hari Amaq Tempiq Empiq pergi ke butan dan setelah kembali lalu menukarnya dengan kebutuhan pokok lainnya.

Setiap hari ketika Amaq Tempiq Empiq akan pergi ke butan untuk mencari kayu api, ia berpesan pada istrinya. "Inaq Tempiq Empiq, kalau nasi sudah masak, tinggalkan aku keraknya, akan kumakan setelah kembali dari butan."

Amaq Tempiq Empiq memang biasa memakan kerak setiap bari. Karena isterinya selalu menyediakan setiap hari (Depdikbud, 1984: 85).

Amaq Tempiq merupakan suami yang bertugas untuk mencari kayu bakar untuk memenuhi kebutuhan pokok keluarganya. Hutan dapat dipandang sebagai ruang atau medan kekuasaan tokoh Amaq dalam cerita. Secara konotatif atau di tataran makna kedua, hutan merupakan simbol kebebasan dan kehidupan liar, sebuah arena 
yang hanya dapat diarungi dan ditaklukkan oleh pria. Sedangkan sang istri berada di rumah setiap hari untuk memasak dan menyiapkan makanan kepada keluarganya. Ruang lingkup aktivitas perempuan hanya terbatas di rumah. Dapat dilihat dari kutipan diatas bahwa sepasang suami isteri ini melakukan aktivitas yang sama setiap hari dan telah saling menyadari peran masing-masing. Dikotomi peran ini perlahan menimbulkan rasa kuasa yang dimiliki suami terhadap keluarga khususnya isteri karena suami merasa memikul peran yang lebih produktif dan mulia.

"Hai perempuan celaka, hanya soal kerak nasi saja kau tak dapat mengatasinya. Bosan aku mendengar Tempiq-Empiq terus merengek kepadaku. Di mana kepalamu, bai otak udang” (Depdikbud, 1984: 86).

Kutipan di atas menunjukkan kekerasan verbal yang dilakukan Amaq kepada isterinya melalui lontaran ujaran-ujaran kasar. Perempuan dalam hal ini dipandang hanya sebagai makhluk domestik, terbelakang, dan marginal. Kata celaka mengandung pengertian bahwa perempuan dipandang lemah dan bodoh dalam menyelesaikan permasalahan. Frasa otak udang berarti orang yang dungu dan sukar memahami sesuatu. Di balik ujaran tersebut, pemaknaan lapis konotatif terhadap ungkapan itu yakni pandangan atas ketidakmampuan perempuan untuk menggunakan akal dan nalar, betapa perempuan hanya berkutat pada aktivitas rumah dan reproduksi belaka. Kekuasaan suami juga nampak pada bagian cerita yang menunjukkan ego Amaq yang tidak pernah mengindahkan saran isterinya. Hal ini menunjukkan bahwa suami sebagai pemegang tampuk kekuasaan di rumah memiliki hak untuk memutuskan dan pendapat istri dinilai tidak berarti. Sikap Amaq Tempiq Empiq yang merasa memiliki tanggung jawab yang lebih besar dibandingkan isterinya juga nampak jelas dalam kutipan berikut ini.

Sambil berjalan mondar-mandir di dapur, Amaq Tempiq-Empiq melanjutkan amarahnya. "Hai perempuan dungu, pasanglah telingamu dan dengar kata-kataku. Besok pagi pergilah ke butan. Aku tinggal di rumah. Kamu sanggup? Cepat jawab"

..."Cepat jawab. Kamu sanggup atau tidak? Kalau tidak sekarang juga terima bagianmu ini."

Selesai berkata demikian, Amaq Tempiq-Empiq langsung mengambil sepotong kayu yang kebetulan berada di dekatnya. Kayu itu kemudian dipukulkan ke tubuh isterinya (Depdikbud, 1984: 86).

Saat marah, Amaq Tempiq Empiq menantang istrinya untuk bertukar peran yang sebenarnya menegaskan sebuah keyakinan bahwa pekerjaan dan tanggung jawab yang dipikulnya jauh lebih besar dan berat dari sang isteri. Istri yang dinilai hanya mengurus kebutuhan rumah tangga dianggap tidak berarti jika dibandingkan pekerjaan yang harus dipikul suaminya. Ini kemudian menegaskan relasi hierarki yang terbentuk antara suami dan isteri. Sehubungan dengan ujaran-ujaran bernada negatif yang dilontarkan Amaq kepada istrinya, kata dungu pada kalimat di atas kembali menegaskan kedudukan Inaq sebagai istri di mata suaminya. Perempuan dalam hal ini hanya diposisikan layaknya properti atau bahkan makhluk pasif yang tidak berakal. Hal ini semakin diperkuat dengan tindakan kekerasan yang bermuara pada kekerasan fisik yang dilakukan Amaq kepada istrinya, Inaq. Perempuan hanya diperlakukan layaknya objek tidak bernyawa karena hak milik terhadap jiwa dan tubuhnya berada di tangan suami. Ini merupakan bentuk ketidakadilan dan ketimpangan gender yang terjadi dalam masyarakat, khususnya keluarga.

Relasi gender dalam cerita rakyat berjudul Tempiq Empiq ini juga dapat ditinjau dari objek telur sebagai hal berharga yang diberikan sang ibu Inaq kepada anaknya. Telur merupakan simbol kehidupan baru dan kelahiran kembali. Ibu menukar jiwanya dengan telur yang diharapkannya dapat berguna bagi anak-anaknya. Sayangnya telur itu disalahgunakan kembali oleh sang ayah. Peristiwa ini merepresentasikan pengorbanan perempuan dalam kehidupan rumah tangga. Dalam pandangan masyarakat, perempuan 
diharuskan tunduk dan mengabdikan diri kepada suami sekalipun mendapatkan tindakan diskriminatif. Kewajiban mengurus dan membesarkan anak seolah hanya menjadi beban dan tanggung jawab perempuan. Kepergian ibu dari rumah seperti yang dikisahkan dalam cerita, menandakan akhir dari derita yang dialami. Ibu dalam hal ini melepaskan diri dari statusnya sebagai istri dan ibu, melakukan perjalanan yang pada akhirnya memberi kebebasan kepadanya dari sejumlah beban yang harus dipikulnya semasa hidup, berubah menjadi makhluk mitis penghuni gua, yang tidak terdefinisikan dan tidak terikat terhadap hal apapun.

\section{b. Mencari llmu Berumah Tangga}

Analisis yang dilakukan di tataran kedua teks cerita rakyat Mencari Ilmu Berumah Tangga juga menunjukkan adanya mitos seksualitas di dalamnya. Cerita ini tidak hanya menceritakan tentang seorang perempuan yang taat beribadah dan diwajibkan untuk menguasai pengetahuan berumah tangga oleh orangtuanya. Pada lapisan makna konotatif, ini mengindikasikan bahwa perempuan terlatih dan dipersiapkan untuk menjadi makhluk rumahan. Ada linieritas antara tokoh Inaq dalam cerita rakyat sebelumnya dan tokoh perempuan pada cerita rakyat ini. Kedua tokoh perempuan ini menghadapi situasi yang sama. Rumah menjadi ruang aktualisasi diri mereka melalui sejumlah aktivitas yang berkutat pada sumur, dapur, dan kasur. Kedua cerita rakyat menunjukkan adanya pembagian peran secara seksual dalam ranah domestik. Kutipan berikut menegaskan sejumlah tugas dan kewajiban yang dibebankan pada perempuan.

Jadi seumpama suamimu main-main dengan perempuan lain, kau harus tetap sabar janganlah marah. Apabila pakaiannya kotor segera kau cuci sepatunya engkau bersibkan setiap bari. Makanannya harus selalu kau sediakan. Nasi jangan sampai dingin, demikian juga air minumnya. Apabila telah dingin, segera kau ganti dengan baru. Walau ia tidak pulang beberapa bari lamanya, hal yang serupa itu tetap kau lakukan.

Pada saat suamimu tidak ada di rumah, bagaimanapun keadaannya, kau harus tetap mengerjakan sembahyang, jangan melalaikannya walau sesaat pun. Setiap malam kau bacalah Al Quran.

Apabila tetanggamu bertanya kemana suamimu, katakanlah pergi bekerja, walaupun kau tidak. tabu kemana ia pergi.

Itulah ilmu bersuami yang paling baik, kata nenek itu mengakbiri wejangannya (Depdikbud, 1981: 80).

Kedudukan perempuan sebagai makhluk kelas dua dapat dilihat melalui penggalan cerita di atas. Dalam lapis makna konotatif, kalimat pertama mengindikasikan bahwa perempuan diharuskan untuk berlaku pasif mengabaikan perasaannya ketika menghadapi persoalan rumah tangga. Pembungkaman terhadap perempuan ini bertujuan untuk melanggengkan superioritas laki-laki. Laki-laki dalam hal ini diposisikan lebih unggul jika dibandingkan dengan perempuan yang hanya berkiprah dalam urusan merawat rumah dan mengurus anak. Relasi hirarki yang mendapat legitimasi dari masyarakat ini mengarah pada perilaku sewenang-wenang. Secara umum, penyelewengan suami dianggap sebagai tindakan yang lumrah dan biasa terjadi. Sementara itu, kemuliaan perempuan terletak pada sikap diam atas perbuatan suaminya. Sosok nenek dalam cerita tentu tidak hanya hadir sebagai sosok yang berpengetahuan dan berpengalaman dalam ilmu berumah tangga. Kehadirannya mengindikasikan ketidakmampuan tokoh perempuan untuk menentukan dan memutuskan jalan hidupnya sendiri. Putri saudagar dalam hal ini kehilangan kemandiriannya dan kemerdekaannya sebagai manusia dan menggantungkan nasibnya pada perkataan nenek tersebut. Ironisnya, isteri yang baik dalam perspektif nenek itu justru istri yang tetap bungkam meskipun menerima ketidakadilan dan perlakuan serong dari suaminya. Hal yang ditunjukkan melalui kutipan di atas adalah perempuan bertugas penuh melayani suami mulai dari makan dan minum sampai menyiapkan 
pakaian. Perempuan diposisikan untuk bersabar, tunduk dan patuh terhadap segala perlakuan suami. Hal ini semakin dipertegas melalui kutipan berikut.

Keesokan harinya, walaupun suaminya tidak ada, si isteri pagi-pagi sekali sudah bangun. Sepatu suaminya dibersibkannya. Diletakkannya celana dalam dan sarung di tempat mandi. Nasi dan lauk pauknya, juga disediakan. Seperti itulah yang dilakukannya sampai bari ketiga (Depdikbud, 1981: 81).

"Mulai sehari sesudah perkawinan, dia sudah tak dirumah, tetapi saya tetap menyediakan makanan dan pakaiannya setiap hari" kata perempuan itu (Depdikbud, 1981: 82).

Doktrinasi sang nenek berhasil dan dijalankan dengan sempurna oleh tokoh perempuan. Bagaikan robot berjalan yang bergerak secara otomatis, ia seumpama pelayan yang tetap bekerja meskipun tuan rumah sedang tidak berada di rumah. Lembaga pernikahan hanyalah peralihan status belaka karena baik istri dan suami tidak menjalankan peran dan fungsinya sebagaimana mestinya. Isteri hanya disibukkan dengan perawatan rumah dan pemenuhan kebutuhan suami, sementara suami menghabiskan waktu di luar rumah meskipun bukan untuk kepentingan kerja. Pembagian peran secara seksual tergambar dengan jelas melalui bagian cerita di atas. Rumah menjadi sarana pengejawantahan diri istri sementara suami megaktualisasikan dirinya di arena publik. Pandangan masyarakat terhadap citra dan gambaran ideal kehidupan berumah tangga direpresentasikan oleh nenek yang memiliki andil yang besar dalam menuntun dan mengarahkan tutur dan tingkah laku tokoh perempuan. Ini menunjukkan bahwa kondisi eksternal memilki pengaruh yang besar dalam membentuk identitas subjek. Kedudukan perempuan dalam pandangan masyarakat juga tergambar melalui kutipan berikut.

Ujilah olehmu, siapa yang mau memandikan, menggosok badanmu mengganti pakaian dan membawamu masuk ke dalam rumah. Wanita seperti itulah yang patut kau jadikan isteri diantara sekian banyak perempuan kau kenal (Depdikbud, 1981: 85).

Kutipan ini semakin mempertegas pandangan masyarakat terkait kriteria isteri yang ideal. Keberhasilan seorang istri dalam hal ini diukur dari seberapa bagus ia merawat suaminya sampai kepada urusan privat yang sebenarnya bisa dilakukan sendiri oleh lelaki. Berdasarkan pemaknaan pada tataran kedua, pernyataan di atas mengindikasikan inferioritas perempuan. Kalimat tersebut diucapkan oleh tokoh kakek dalam cerita yang kembali menegaskan pandangan masyarakat terhadap relasi hierarki dalam institusi pernikahan. Serupa dengan tokoh nenek yang memandu kehidupan perempuan, kehadiran sosok kakek dalam cerita juga menandakan ketidakmampuan lelaki tersebut untuk menentukan jalan kehidupannya sendiri. Suami yang dalam perspektif masyarakat lekat dengan karakter kuat, mandiri, dan berwibawa justru menunjukkan kerapuhannya melalui tokoh kakek yang kembali menuntun lelaki tersebut dalam mengarungi kehidupan rumah tangganya. Kakek berperan menjejali tokoh lelaki mengenai posisi perempuan dalam rumah.

Perintah Raja kepada anaknya. "Mau tidak mau kau harus pergi berlayar, berdagang, kau sudah punya isteri, harus mencari penghidupan baru. Saya tidak mau kalau tetap menggantungkan bidupmu padaku (Depdikbud, 1981:82).

Peran seorang suami terhadap isteri juga tergambar melalui kutipan di atas. Profesi laki-laki dalam cerita ini adalah berlayar dan berniaga. Lautan merupakan ruang dan medan yang luas, liar, dan penuh tantangan. Lautan sebagai latar lain dalam cerita mengindikasikan kekuasaan dan arena yang hanya dapat diarungi dan dijamah oleh lelaki. Kutipan tersebut juga menunjukkan bahwa laki-laki memiliki kewajiban untuk menafkahi isterinya dan lebih banyak melakukan pekerjaan di luar rumah. Hal tersebut tentu membentuk dualisme peran antara perempuan dan laki-laki yang merasa memiliki kedudukan yang lebih tinggi serta tugas dan fungsi yang lebih besar, produktif, dan 
penting dibandingkan perempuan yang hanya berkutat pada aktivitas rumah yang seringkali dipandang sebagai pekerjaan gratis kontra produktif.

Inferioritas dan subordinasi perempuan juga nampak jelas dalam cerita rakyat Mencari Ilmu Berumah Tangga. Dalam cerita, perempuan menerima julukan-julukan kasar dan kekerasan karena profesi yang digelutinya. Hal ini nampak jelas dalam beberapa kutipan yang dirangkum berikut.

Dia sedang mengunjungi kekasibnya Si Bawen Sundal. Bawen Sundal adalah wanita bajingan yaitu perempuan nakal (Depdikbud, 1981:81).

Dia tidak pergi ke tempat isterinya, tapi ke rumah gendaknya, ke rumah perempuan sundal (Depdikbud, 1981:83).

Ketuju perempuan sundal itu dibuang ke tengah laut, tidak boleh lagi tinggal di negeri itu, sebab mengacau kehidupan anak raja (Depdikbud, 1981: 88).

Kata sundal, bajingan, nakal, dan gendak merupakan sejumlah julukan bagi perempuan yang berprofesi sebagai pelacur. Ada pandangan yang kontras antara perempuan sebagai istri dan tunasusila. Istri yang berdiam di rumah, bersikap pasif dan pasrah terhadap segala penindasan dan kekerasan yang dilakukan suami dipandang sebagai sebuah kemuliaan. sementara itu, seorang wanita yang menjajakan diri secara gratis, bebas, dan tidak terikat dalam hubungan pernikahan dipandang sebagai perempuan yang tidak beradab dan tidak layak berada di tengah masyarakat. Jika ditelisik lebih mendalam, baik perempuan di dalam rumah dan perempuan yang berkiprah di luar rumah sama-sama menerima laku diksriminatif dari masyarakat. Kutipan di atas menunjukkan betapa perempuan diperlakukan tidak manusiawi, dilenyapkan dan dibuang seumpama barang yang jika tidak dipakai lagi maka dapat disingkirkan. Ini menunjukkan kekuasaan dan dominasi yang dimiliki oleh laki-laki khususnya yang memegang jabatan sebagai penguasa atau raja. Berdasarkan pandangan agama masyarakat Kalimantan Selatan, para perempuan yang dipandang amoral seperti tokoh-tokoh dalam cerita ini layak untuk disisihkan dari masyarakat.

\subsection{Ideologi Patriarki dan Mitos Maskulinitas dalam Cerita Rakyat}

Cerita rakyat Tempiq Empiq merupakan cerita yang berasal dari daerah Nusa Tenggara Barat. Cerita rakyat menjadi refleksi kondisi sosial budaya masyarakat yang melatarbelakangi cerita tersebut. Nusa Tenggara Barat khususnya suku Sasak merupakan daerah yang menganut sistem patriarki/patrilineal (laki-laki menjadi sumber utama). Poligami merupakan hal yang lumrah dimana para istri tinggal bersama dalam satu rumah. Sistem patriarki akhirnya menempatkan anak laki-laki pada posisi yang yang lebih tinggi sedangkan perempuan berada pada posisi lemah dan tidak diperkenankan untuk protes atau menentang keluarga termasuk ketika ingin dipoligami. Bahkan terdapat adat pernikahan Sasak yang disebut Merariq yang mewajibkan laki-laki untuk mencuri perempuan yang akan dijadikan isterinya (Efendi, 2010).

Demikian pula cerita rakyat Mencari ilmu Berumah Tangga yang berasal dari Kalimantan Selatan menggambarkan kondisi sosial-kultural masyarakat setempat. Berdasarkan sistem kekeluargaan di Kalimantan Selatan yang patriarki, kaum laki-laki memiliki hak istimewa dibandingkan kaum perempuan yang telah mengakar kuat dalam tradisi budaya Banjar. Perspektif yang berkembang di masyarakat bahwa arena perempuan berada di area privat/rumah menjadikan mereka tidak bebas berkiprah di ranah publik (Salasiah, dkk., 2015: 97).

Relasi hierarki antara perempuan dan laki-laki terbentuk oleh stereotip gender. Stereotip gender merupakan prasangka yang cenderung negatif yang mengarah kepada tindakan diskriminatif. Stereotip berkaitan dengan ketimpangan gender yang melahirkan diskriminasi berdasarkan jenis kelamin. Laki-laki memiliki dominasi dan 
perempuan dalam hal ini berada dalam posisi tersubordinasi atau dipandang tidak bernilai dan berarti. Bhasin (1996: 11) mengemukakan bahwa keluarga sebagai institusi terkecil merupakan ruang penerapan sistem patriarki. Dalam keluarga, laki-laki dipandang sebagai kepala rumah tangga yang mengendalikan seksualitas, produksi, reproduksi, dan mobilitas perempuan. Relasi hierarki terbentuk ketika derajat laki-laki lebih tinggi dan berkuasa, sedangkan perempuan lebih rendah dan dikuasai. Keluarga juga akhirnya mewariskan nilai-nilai patriarkal kepada generasi selanjutnya. Keluargalah yang telah memperkenalkan mengenai hierarki, subordinasi, dan diskriminasi.

Isu bias gender yang tersingkap dalam cerita rakyat Tempiq Empiq dan Mencari Ilmu Berumah Tangga merupakan representasi dari ideologi patriarki yang dianut oleh masyarakatnya. Patriarki merupakan sebuah pandangan bahwa laki-laki memiliki dominasi dan menempati posisi superior. Perempuan dalam hal ini menjadi pihak yang dikuasi melalui berbagai macam cara, dikendalikan, direduksi sebagai sosok yang lemah, pasif, dan tak dapat bersuara. Ideologi yang dipahami sebagai kesadaran palsu disisipkan dalam cerita rakyat tersebut melalui mitos seksualitas atau adanya dualisme peran dan fungsi laki-laki dan perempuan serta nilai-nilai atau mitos maskulinitas berupa simbol-simbol kekuasaan yang dimiliki oleh laki-laki. Bahasa merupakan alat legitimasi pandangan patriarki yang memosisikan laki-laki sebagai subjek, kuat, dan berkuasa sementara perempuan menjadi objek yang dieksploitasi.

\section{$4 \quad$ PENUTUP}

Bias gender menjadi persoalan yang kerapkali mewarnai cerita rakyat Indonesia. Analisis yang dilakukan terhadap dua cerita rakyat yang berjudul Tempiq Empiq dan Ilmu Berumah Tangga menunjukkan ketimpangan gender. Dikotomi peran dan aktivitas lakilaki dan perempuan mengarah kepada sebuah relasi hierarki yang membuat laki-laki merasa memiliki beban kerja, tugas, dan tanggung jawab yang lebih besar dibandingkan perempuan. Sedangkan perempuan hanya berkutat pada tugas domestik seperti melayani suami, mengurus segala keperluan rumah, dan merawat serta membesarkan anak. Hal ini kemudian menempatkan perempuan pada posisi inferior dan tersubordinasi. Melalui pembacaan pada lapis makna di tingkat pertama dan kedua atau yang dipahami dalam istilah denotasi dan konotasi ditemukan sejumlah tanda yang mengarah pada mitos seksualitas dan maskulinitas. Mitos tersebut mengungkapkan ideologi yang terkandung di balik cerita rakyat tersebut. Kedua cerita rakyat menunjukkan ideologi bias gender dan patriarki yang berlaku dalam kebudayaan dan diwariskan dari satu generasi ke generasi selanjutnya. Tidak ada penyadaran gender yang dibangun melalui kedua cerita tersebut melainkan hanya tahap penyelesaian konflik dan penyesalan tokoh laki-laki atas tindakan yang dinilai salah.

\section{DAFTAR PUSTAKA}

Banton, Michael. 1994. Discrimination. USA: Open University Press.

Barthes, Roland. 1981. Elements of Semiology. New York: Hill and Wang.

Barthes, Roland. 1957. Mythologies. Diterjemahkan oleh: Annette Lavers. New. York: The Noonday Press.

Barthes, Roland. 1974. S/Z. Penerjemah Richard Miller. New York: Hill and Wang

Bhasin, Kamla. 1996. Menggugat Patriarki. Yogyakarta: Bentang.

Depdikbud. 1981. Cerita Rakyat Daerah Kalimantan Selatan. Jakarta: Departemen Pendidikan dan Kebudayaan.

Depdikbud. 1984. Cerita Rakyat Daerah Nusa Tenggara Barat. Jakarta: Departemen Pendidikan dan Kebudayaan. 
Efendi, Yusuf. 2010. Sekurenan, dan Sorohan: Keluarga dan Kekerabatan Suku Sasak, Nusa Tenggara Barat, http://melayuonline.com/ind/culture/dig/2599/sekurenandan-sorohan-keluarga-dan-kekerabatan-suku-sasak-nusa-tenggara-barat, diakses tanggal 2 Desember 2016.

Endraswara, Suwardi. 2011. Metodologi Penelitian Sastra. Yogyakarta: CAPS.

Fakih, Mansour, 1997. Analisis Gender dan Transformasi Sosial. Yogyakarta: Pustaka

Pelajar.

Faruk, 2015. Metode Penelitian Sastra. Yogyakarta: Pustaka Pelajar.

Junaini, dkk. 2017. “Analisis Pendidikan Karakter dalam Cerita Rakyat Seluma.” Jurnal KORPUS. Vol.1, No. 1, Agustus 2017.

Nasiru, La Ode Gusman. 2017. "Transformasi Perempuan dari "Liyan" ke "Diri" dalam Tiga Cerita Rakyat Kulisusu: Analisis Wacana Feminisme." Poetika: Jurnal Ilmu Sastra. Vol. V, No. 1, Juli 2017.

Noy, Novianti, dkk. 2016. "Analisis Unsur Intrinsik dan Nilai-Nilai Cerita Rakyat Dara Buak dari Suku Dayak Mualang Desa Tapang Pulau Kecamatan Belitang Hilir Kabupaten Sekadau." Jurnal KANS ASI. Vol.1, No.1, April 2016.

Pradopo, Rachmat Djoko. 2013. Beberapa Teori Sastra. Metode Kritik, Dan Penerapannya. Yogyakarta: Pustaka Pelajar.

Ratna, Nyoman Kutha. 2013. Teori, Metode, dan Teknik Penelitian Sastra. Yogyakarta: Pustaka Pelajar.

Safiuddin, Salmatian. 2019. "Analsis Semiotika Pada Cerita Rakyat Wandiu-Ndiu." Jurnal LAKON. Vol. 8, No.2.

Salasiah, dkk. 2015. "Peranan Perempuan Banjar Dalam Pendidikan Islam Abad XIX dan XX." Mu'Adalah Jurnal Studi Gender dan Anak. Vol. III, No.2, hal. 97-110.

Sugihastuti, dkk. 2007. Gender dan Inferioritas Perempuan: Praktik Kritik Sastra Feminis. Yogyakarta: Pustaka Pelajar.

Sugihastuti. 2011. Teori Apresiasi Sastra. Yogyakarta: Pustaka Pelajar. 